\title{
FESTUNG EUROPA: SECURITIZATION OF MIGRATION AND RADICALIZATION OF EUROPEAN SOCIETIES
}

\author{
MONIKA GABRIELA BARTOSZEWICZ \\ VISTULA UNIVERSITY
}

\begin{abstract}
Europe is undoubtedly changing into Festung Europa - Fortress Europe. While its external boundaries are daily traversed by hundreds of migrants and refugees, its heretofore invisible internal borders have begun to sprout barbed wires, barriers and armed patrols. This paper analyzes the problem of migration and the ongoing European migration crisis through the lens of societal insecurity, arguing that the trend toward radicalization of European societies and electoral politics is one the most volatile ramifications of securitized migration. The European migration crisis has led to a societal security dilemma resulting in a growing chasm between the political elites in member states of the European Union and their societies. The radicalization of those societies is visible in the rising popularity of anti-establishment (populist) parties, the push for direct democracy (demonstrations, manifestations, referenda), and the attractiveness of vigilante groups. Where the state responds to this trend, culture becomes a security policy and "immiskepticism" is the default approach. If it does not respond, society either looks for new political representatives or takes matters into its own hands, sometimes resorting to violence. While the former trend is more visible in the Eastern part of the European Union, the latter is more typical of its Western part.
\end{abstract}

Keywords: Europe; European migrant crisis; migration; politicization; securitization; radical politics; societal insecurity

DOI: $10.14712 / 23363231.2017 .10$

\section{Introduction}

The traditional approach to societal security was designed to tackle the changing reality in post-Cold War Europe and adjust to new settings. It was

Dr. Monika Gabriela Bartoszewicz is Associate Professor of International Relations at Vistula University, Warsaw. Address correspondence to Vistula University, ul. Stokłosy 3 02-787 Warszawa, Poland. E-mail: mgbartoszewicz@gmail.com. 
conceived in order to deal with the emerging political importance of the European Union (EU) and placed heavy emphasis on society as the focal point of European security concerns. If societies constitute the fulcrum of the security agenda, then the issues connected with migration underpin many perceived threats and vulnerabilities. States need independence to survive, but for societies, survival is determined by identity. Consequently, processes that undermine, disrupt or weaken a society's identity lead to societal insecurity, particularly when a society defines a given change, development or potentiality as a threat to its survival as a community. ${ }^{1}$ An insecure society does not resort to military action; rather, it turns to processes that strengthen and juxtapose "us" versus "them." This leads to situations where one identity is challenged by another and each reinforces the other, reciprocally, leading to a societal security dilemma.

This paper analyzes the problem of migration through the lens of societal insecurity in the context of the European migration crisis, which is conceptualized here as a catalyst for political (securitization) and societal (radicalization) change. This theory implies that a vast influx of immigrants to Europe in a relatively short time span threatens society with powerful inflows of different languages, styles, cultures, and values that can weaken or even overwhelm their indigenous counterparts and damage the ability of local identities to reproduce themselves, leading to the afore-mentioned societal security dilemma. The theoretical foundations of this argument are laid out in the first part of this analysis.

Migration was already politicized in Europe before the current crisis. The German Interior Ministry estimated in 2008 that as many as 6 million immigrants were residing in Europe without a residence permit, and that each year that figure was growing by 4.5 to 8 million. ${ }^{2}$ Migration, particularly irregular migration, was even then an important, but not the most important, problem on the political agendas of European leaders, both on the national and EU level. Although it was a divisive issue, this division cut vertically through all social strata and debate occurred mainly on the political margins. Furthermore, polarized groups holding various opinions did not have any capability to influence mainstream policies. Fringe parties like the Front National in France essentially existed as a form of political folklore. To a large extent, these various groups' existence was possible only because they differed from the political mainstream in all main respects, including their attitudes toward migration, and few took them seriously.

1 Barry Buzan, Ole Wæver, and Jaap de Wilde, Security: A New Framework for Analysis (London: Lynne Rienner, 1998), 119.

2 “Sarkozy Fails to Push through Fortress Europe Plan,” Der Spiegel, July 8, 2008, http://www.spiegel .de/international/europe/0,1518,564674,00.html. 
The year 2015 changed the situation dramatically. When Angela Merkel pledged to provide refuge to anyone seeking protection from violence and war abroad, she declared that Germany would not be a country closed to those in need and hostile to refugees. ${ }^{3}$ But European societies quickly became increasingly "immiskeptical." 4 More and more people believe that a country reluctant to put the needs and interests of its own society first is not their country and that politicians unwilling to defend their own constituencies, social systems, laws, cultures, and borders are not their politicians. The second, interpretative part of this paper explains how migration is at the root of societal insecurity and leads to a societal security dilemma.

Migration and migration-related policies are now shaping the European political landscape. Debates on border policies, irregular and economic migrants, refugees and asylum seekers, relocation schemes and integration programs reveal not a vertical but a horizontal societal fracture. There is a rift, a growing chasm, between the national and European political elites and their respective societies. Societies have discovered that EU officials are quite willing to announce sweeping and potentially irreversible societal changes, proclaiming that they are "inevitable" and that people will just have to adapt and get used to them. ${ }^{5}$ What is more, the political establishments in the EU member states have to a large extent only nodded in accord. But whereas Commissioners and High Representatives are neither elected by nor accountable to Europeans, national politicians are. Societies which do not feel they are represented seek new representation. Consequently, the final part of this analysis shows how the societal insecurity triggered by migration manifests itself in the political radicalization of societies, as evidenced by the rising popularity of anti-establishment (populist) parties, a push for direct democracy (demonstrations, manifestations, referenda), and the attractiveness of vigilante groups. Contrary to other analyses, ${ }^{6} \mathrm{my}$

3 “Mother Angela: Merkel’s Refugee Policy Divides Europe," Der Spiegel, September 21, 2015, http:// www.spiegel.de/international/germany/refugee-policy-of-chancellor-merkel-divides-europe -a-1053603.html.

4 In Great Britain, more than 60 percent of the population, and in France nearly 70 percent, believes migration to be divisive and harmful because immigrants do not want to adjust to European values, according to research carried out by French IFOP, http://www.ifop.com/media/poll/3315-1 -study_file.pdf, and British Populus, http://www.populus.co.uk/wp-content/uploads/2016/01 /download_pdf-180506-The-Daily-Politics-Immigration.pdf. Links direct to reports with details regarding survey results and methodology.

5 Andrew Bounds, "EU told to accept 20m migrant workers," The Financial Times, September 13, 2007, https://www.ft.com/content/a23dbdaa-6164-11dc-bf25-0000779fd2ac.

6 Jeanne Park, Europe's Migration Crisis (New York: Council on Foreign Relations, 2015); Simone Bertoli, Herbert Brücker and Jesús Fernández-Huertas Moraga, “The European crisis and migra- 
paper does not ascribe this rising popularity to a single phenomenon like economic concerns or xenophobia, but it does acknowledge that these are indirect factors resulting from the societal insecurities that are a by-product of migration. Where the state responds, culture itself becomes a security policy and "immiskepticism" is the default attitude underlying action. Otherwise, societies either look for new political representatives, voting for political forces that securitize migration, or they take matters into their own hands, forming vigilante groups or resorting to violence. While the former trend is more visible in the Eastern part of the European Union, the latter is more typical for the Western part.

\section{Societal In/security}

In security studies, many battles have been fought over the depth and breadth of the security concept. For some, intangible factors such as identity, culture and religion constitute invisible frontlines, borders not to be trespassed. For others, these factors are powerful, albeit cumbersome weapons that are efficient yet difficult to wield. The focus of the traditional school of thought, centered on states, tended to ignore less material and palpable influences in international relations - even though they certainly have an impact on political actors. ${ }^{7}$ The critics of the traditional approach, on the contrary, embrace the concept of human security and drive the focus of analysis down to the level of the individual. ${ }^{8}$ However, this shift from the structural to the cognitive fails to acknowledge the unifying agency transmitted by the individual to groups and communities as a whole. In between these propositions, one can find a theoretical framework developed by scholars at the Conflict and Peace Research Institute (COPRI),

tion to Germany," Regional Science and Urban Economics 60 (2016): 61-72; or Peter Scholten and Frans van Nispen, "Policy analysis and the 'migration crisis': Introduction," Journal of Comparative Policy Analysis: Research and Practice 17, No. 1 (2015): 1-9.

7 With respect to the traditional works, readers should consult Kenneth N. Waltz, Theory of International Politics (Long Grove, IL: Waveland Press, 2010); John J. Mearsheimer, The Tragedy of Great Power Politics (New York: W.W. Norton, 2001); Robert O. Keohane, After Hegemony: Cooperation and Discord in the World Political Economy (Princeton, NJ: Princeton University Press, 2005); and Michael W. Doyle, Ways of War and Peace Realism, Liberalism, and Socialism (New York: Norton, 1997) among others.

8 Starting with Hedley Bull, The Anarchical Society: A Study of Order in World Politics (Basingstoke: Palgrave Macmillan, 2012) and Emanuel Adler and Michael Barnett, Security Communities (Cambridge: Cambridge University Press, 1998) and moving on to the analysis prepared by the Human Security Centre, Human Security Report (Oxford: Oxford University Press, 2005), also available at www.humansecurityreport.info, and Roland Paris, "Human security: Paradigm shift or hot air?" International Security 26, No. 2 (2001): 87-102. 
collectively known as the Copenhagen School (hereinafter referred to as Buzan et al.). Barry Buzan there introduced the central concept of societal security, which was later elaborated by Ole Wæver in an attempt to bring together the material and the invisible, reconcile objectivity and construction, and combine the collective and the individual. ${ }^{9}$

One of the fundamental assumptions governing the societal security concept is that the state and a society "of the same people" are two different things. ${ }^{10}$ Consequently, the security of the state and security of a society are two different "securities" derived from two different sources: the former from sovereignty, the latter from "patterns of language, culture, religious and national identities, and customs of states"11 - in short, from identity. Wæver argues that states can be undermined and destabilized by "their" societies being threatened or weakened in terms of social cohesion and identity. Society is thus more than just an aspect of state security through which the state's security can be threatened; it becomes a referent object with its own security concerns. Since societal identity is able to reproduce itself independently of the state and even in opposition to it, it should be considered as something integral to, yet at the same time independent of, state security. ${ }^{12}$

Societies are understood here as large-scale collective units of individuals (and yet more than the sum of individual people) with a profound element of

9 This analysis is based on the following works discussing the concept and ramifications of societal security: Barry Buzan et al., The European Order Recast: Scenarios For the Post-Cold War Era (London and New York: Pinter, 1990); Ole Wæver et al., Migration And the New Security Agenda in Europe (London: Pinter, 1993); Barry Buzan, Ole Wæver and Jaap de Wilde, Security: A New Framework For Analysis (London: Lynne Rienner, 1998); and Barry Buzan and Ole Wæver, Regions and Powers: The Structure of International Security (Cambridge: Cambridge University Press, 2003). By doing so, this paper does not follow the critical studies on societal security, like that of Didier Bigo, "Security and immigration: toward a critique of the governmentality of unease," Alternatives 27, No. 2 (2002): 63-92; Didier Bigo and Anastassia Tsoukala, eds., Terror, Insecurity and Liberty: Illiberal Practices of Liberal Regimes after 9/11 (London: Routledge, 2008); or Jef Huysmans, "The European Union and the Securitization of Migration," JCMS: Journal of Common Market Studies 38, No. 5 (2000): 751-77. Furthermore, as this paper focuses on European affairs and political science, works like Mark B. Salter, "Securitization and desecuritization: a dramaturgical analysis of the Canadian Air Transport Security Authority," Journal of International Relations and Development 11, No. 4 (2008): 321-49, epistemological enquiries like Claudia Aradau, "Political grammars of mobility, security and subjectivity," Mobilities 11, No. 4 (2016): 564-74, and Michael Williams, Culture and Security: Symbolic Power and the Politics of International Security (London: Routledge, 2007), are not taken into consideration.

${ }^{10}$ Buzan et al., The European Order Recast, 119.

${ }^{11}$ Barry Buzan, People, States \& Fear: An Agenda for International Security Studies in the Post-Cold War Era (Colchester: ECPR Press, 2008), 122-23.

12 Wæver et al., Migration and the New Security, 24-25. 
mutual orientation (or sense of belonging) grounded in structures, institutions, and practices. ${ }^{13}$ Society's kernel is identity (i.e., all that enables a group of people to refer to themselves as "we"), the self-concept of a community and of individuals identifying themselves as members of that community. ${ }^{14}$ Naturally, the sense of shared heritage varies with respect to the size of the group, the intensity of the group's bond, and the reasons for its construction, but it remains necessary for the existence of every society. However, societal identity does not exist in peace; it experiences inner tensions and conflicts. Simultaneously, it demonstrates a willingness to defend itself against internal or external threats. Analyzed from such a perspective, society has both an objective and a subjective dimension, as well as a social and moral structure.

A society, as opposed to a nation, is not linked to the state. It is clearly distinguishable from other societies. Buzan et al. characterize the nation as a special case of a society defined by affiliation to territory - a community with continuity across time, linking past members to current and future ones "with specific customs, dances and stories, its songs and traditions." 15 Notwithstanding the political deeds and views of individuals (pluralism), nations make people belong together (universalism) in one of the units that make up the global order. ${ }^{16}$ Constructing nationhood is not a question of applying an ambiguous category to various cases into which it fits more or less nicely. It combines two sets of factors, the objective, such as language or location, and the constructed (or inter-subjective), arising from a political or personal choice to identify with some community. ${ }^{17}$

By contrast, citizenship is the legal expression of membership in a national community. ${ }^{18}$ As such, it constructs the identity of individuals according to the role they play in a political community; it establishes the individual's relationship to the state. Simultaneously, it disrupts harmony in the broader society as migration and internationalization blur the distinction between "civic" and "national." In other words, citizenship challenges the relation of an individual to the society. This observation is crucial, because a societal security framework of analysis implies that by having citizenship one can be a part of the nation, while simulta-

13 Ibid., 21-22.

${ }^{14}$ Buzan et al., The European Order Recast, 119.

15 Wæver et al., Migration and the New Security, 21-22.

16 Ibid., 29.

17 Buzan et al., The European Order Recast, 120.

18 William Safran, "Citizenship and Nationality in Democratic Systems: Approaches to Defining and Acquiring Membership in the Political Community," International Political Science Review/Revue internationale de science politique 18, No. 3 (July 1997): 313-35. 
neously being excluded from the society due to cultural factors (ethnicity, religion, language, descent). For a state to be the carrier of an ordinate identity, as Jeff Spinner-Halev notes, would require going through a process of deculturation of the public sphere (similar to secularization) that would make culture a private matter. ${ }^{19}$ However, it is difficult to imagine a culturally neutral state, divorced from any kind of identitive affiliation. Furthermore, the proposition of the state as carrier of ordinate identity is hard to defend from the perspective of a societal security framework which argues that it is not always possible to have multiple identities and that competitiveness in identitive processes might trigger tensions and lead to a societal security dilemma.

The concept of societal security can be applied on the macro-level (e.g., the EU) where due to processes of migration, integration, homogenization, sincretization, and European cosmopolitanism, societies are forced to defend themselves against identitive threats they perceive to be existential. It can also be applied on the micro-level to analyze identitive configurations of national groups, subgroups (e.g., the Scots) and cross-state groups (European Muslims). For this reason, as Wæver et al. claim, on the macro-level "societal security issues may play a key role in determining not just the pace and scope, but also the success or failure of the European integration process." 20 Meanwhile, on the micro-level the concept can be applied to deal with an EU reality suffused by intermestic matters such as migration, where the international mingles with the local to such an extent that it is almost impossible to differentiate between the two. Consequently, societal security dominates two interlocking security discourses, one about mass migration threatening national identities and the other about the revival of nationalism as a threat to Europe. ${ }^{21}$

The core argument of societal security acknowledges that while all people live in a complex constellation of multi-layered identities, most of the time no clear or permanent hierarchy governs those identities. Only when they come closer to conflicting, either literally or metaphorically, does the hierarchy appear. In such cases, it is national identity that tends to organize the other identities around itself as the most important form of large-scale social and political identity. Buzan et al. underlined that the only rival to nationalism has been religion, which is not only sufficiently comprehensive and robust, but also equally capable of reproducing a "we" identity across generations. The original societal security

\footnotetext{
19 Jeff Spinner-Halev and Elizabeth Theiss-Morse, "National Identity and Self-Esteem," Perspectives on Politics 1, No. 3. (September 2003): 515-32.

${ }^{20}$ Wæver et al., Migration and the New Security, 3.

21 Buzan and Wæver, Regions and Powers, 375.
} 
concept did not dwell on the issue of religion. Authors acknowledged religion only when combined with nationalism. Such a typology seems quite inappropriate even if one admits that Northern Ireland, the Balkans or Cyprus were not only theological battlefields. To the contrary, since the prominence of religion in Europe has increased significantly in recent years (in regard to migration, Muslim minorities in Europe, Turkey's prospective membership in the EU) it should be acknowledged as a salient factor and the analytical framework should be modified to accommodate it. However, it is important to note that when religious and national identities reinforce each other they can create very strong identities (e.g. Muslim immigrants vs. indigenous Christian Europeans), and very strong patterns of fear, hostility and societal insecurity. ${ }^{22}$

Contrary to the common perception of religion as a factor that is no longer relevant in the study of international relations, ${ }^{23}$ it still influences politics on the national and international level. Sociologists and political scientists are rediscovering religion as a source of collective and individual identity. ${ }^{24}$ Philip Jenkins argues that when historians look back at our century they most probably will see in religion the most basic, inspiring and destructive force of humanity, steering our approaches to politics, freedom and responsibility, our conceptualizations of nationality and, of course, our conflicts and wars. ${ }^{25}$ At the heart of modernity we observe the de-privatization of religion in the public square. ${ }^{26}$ Thus, religious and ethnic identities in contemporary Europe, fueled as they are by globalization, are being "reconstructed and forged anew by the means of the symbolic materials available in national and religious memories." ${ }^{7}$ JeanPaul Willaime neatly summarizes, saying that while cultural, religious and ethnic identities can be constraining to some degree, they are at the same time intrinsically connected to the concept of security, offering a sense of social belonging

22 Wæver et al., Migration and the New Security, 22-23.

23 Jonathan Fox, "Religion as an Overlooked Element of International Relations", International Studies Review 3, No. 3 (Autumn 2001): 53-73.

${ }^{24}$ Jean-Paul Willaime, "The Cultural Turn in the Sociology of Religion in France," Sociology of Religion 65, No. 4, Special Issue: [Culture and Constraint in the Sociology of Religion] (Winter 2004), 373-89.

25 Philip Jenkins, The Next Christendom: The Coming of Global Christianity (Oxford: Oxford University Press, 2011).

26 Grace Davie, "Europe: The exception that proves the rule?" in Desecularization of the World: Resurgent Religion and World Politics, ed. Peter L. Berger (Grand Rapids, MI: Eerdmans, 1999), 76; Peter L. Berger, "Desecularization of the world," in Desecularization of the World: Resurgent Religion and World Politics, ed. Peter L. Berger (Grand Rapids, MI: Eerdmans, 1999), 9-10; and Jose Casanova, Public Religions in the modern world (Chicago: Chicago University Press, 1990), 106.

27 Buzan, Wæver, Regions and Powers, 384. 
and participation. If religion is considered from a Durkheimian perspective as expressing and reinforcing social solidarity, it implies the importance of religion in defining and maintaining the boundaries of any community of believers. In this context, religion is the most crucial thing to people's interest in maintaining or defining the boundaries between themselves and others. ${ }^{28}$ Indeed, while today references to identity have less to do with reproduction and ascription and more to do with choice, in societal security that choice is restricted and dictated a priori. The boundary between "them" and "us" may change, but the division between them and us is necessary for the existence of the society's identity. In the society's perception, migrants are Muslims and their national affiliation is often of secondary importance.

In this atmosphere, Islam has grown in Europe over the years as a major complication and challenge. It has become the second religion of the continent, a development that has raised practical questions about societal life. ${ }^{29}$ The concerns stem from the order-creating function of culture and its impact on societal identity. Robert Holton's study on the cultural causes of internationalized structures suggests that culture is harder to globalize than economics. ${ }^{30}$ In that context, monotheism, which Islam espouses, encourages the development of imagined communities, and enhances spiritual bonds between believers even when they are separated geographically. What is more, it has particular appeal to those who perceive themselves as excluded from the society.

It has to be emphasized that all people perceived as outsiders are not necessarily immigrants. In this respect Buzan et al. pose a crucial question ${ }^{31}$ as to whether immigrants of different ethnic and cultural backgrounds can become members of a national group not in the state dimension, but in a purely societal one. ${ }^{32}$ This question refers to a situation where individuals born and bred into a certain society are still perceived as strangers, and it is particularly significant with respect to Muslims in Europe. This aspect was omitted in the founding

${ }^{28}$ Hugh Watson and Jeff Boag, "Ethnicity and Religion" (Paper presented at the $50^{\text {th }}$ Annual Pugwash Conference on Science and World Affairs. Queen's College, UK, 2000). Retrieved from Columbia International Affairs Online: http://www.ciaonet.org/conf/wat01/index.html.

29 Among many works tackling this topic, there are two excellent analyses: Olivier Roy, Globalized Islam: The Search for a New Ummah (New York: Columbia University Press, 2004); and Jocelyne Cesari, When Islam and Democracy Meet: Muslims in Europe and in the United States (New York: Palgrave Macmillan, 2004).

${ }^{30}$ Robert Holton, “Globalization's Cultural Consequences," The Annals of the American Academy of Political and Social Science, Vol. 570, Dimensions of Globalization (July 2000): 140-52.

31 Ibid., 22.

32 Wæver et al., Migration and the New Security, 22, 156. 
societal security work of Buzan et al. In Europe's past, this group constituted the main "other," and hence was a point of reference for identity construction. Tomaz Mastnak's thesis proposes that Islam was essential to the formation of European identity, and remains important to its maintenance. He argues that this identity was not formed by Islam but predominantly by the relationship to Islam, and that Europe has from that relationship developed a "collective identity" and the ability to orchestrate action, along with a unity constructed in relation to Muslims as the enemy. ${ }^{33}$

\section{The Societal Security Dilemma: Migration and Culture}

As its name suggests, the idea of a societal security dilemma consists of two concepts: the security dilemma and societal security. Paul Roe explains that "societies can experience processes in which perceptions of 'the others' develop into mutually reinforcing 'enemy' pictures leading to negative dialectics whereby groups tend to define their national identity and national consciousness in negative terms, through distinction from or comparison with neighbors." $34 \mathrm{Com}$ peting identities can either be mutually exclusive or one identity can have overbearing influence that disrupts the reproduction of the other, thereby triggering demands for protection against seductive cultural imports. The term societal security dilemma denotes a process whereby a group perceiving its identity as threatened starts to act in a security mode. ${ }^{35}$

For societal security, as with other forms of security, what is perceived as a threat and what can be objectively considered as threatening may be quite different. Real threats may not be seen accurately. Perceived threats may not be real, and yet still have real effects. Wæver argues that internal threats to society are symptomatic of weak states, ${ }^{36}$ a claim that needs to be scrutinized in the context of the European migration crisis. Furthermore, a societal security dilemma is not a static configuration, but a process with its own dynamics whereby the nature of the threat is liquid and "some changes will be seen as part of a natural process by which identities adjust and evolve to meet alterations in historical circumstances." 37

33 Tomaz Mastnak, Islam and the Creation of European Identity (London: University of Westminster, CSD Perspectives, 1994).

${ }^{34}$ Paul Roe, The Societal Security Dilemma (Copenhagen Peace Research Institute, 1997).

35 Wæver et al., Migration and the New Security, 23, 43-44.

36 Ibid., 43, 49.

37 Ibid., 42. 
Because identity is constructed, threats to identity always depend on something perceived as threatening to "us." In spite of a restricted reservoir of ideas to draw upon, any identity can be constructed in many different ways, and, as Buzan reiterates, the main issue that often decides whether a security conflict will emerge is which self-definition is prevailing in society. ${ }^{38}$ This, one could argue, is the reason why the current identitive debates being evoked in EU member-states by the migration crisis are so important, since they will set the tone for the whole of societal security discourse in the proximate future. These debates, present in virtually every country on the continent, are driven by the issue of migration (as its scope and breadth is formulated in a common European migration policy) and by pressures to accept migrants from outside of the European Community, particularly those coming from the Muslim world.

The vast influx of immigrants to Europe in a relatively short time span threatens society with powerful inflows of language, style, culture, and values that may weaken or overwhelm their indigenous counterparts and damage the ability of local identities to reproduce themselves. ${ }^{39}$ This influx started in the previous century, but it has been exacerbated by the current migration crisis which started in 2015 and brought nearly two million migrants to Europe in that year. ${ }^{40}$ The cultural, ethnic and religious otherness of these migrants, crucial to societal security, is clearly visible in data collated by Frontex, Eurostat, ${ }^{41}$ and the International Organization for Migration (IOM). IOM data reveals that 278,201 people arrived in Europe by the middle of August 2016, compared to 219,854 over the same period the preceding year, which indicates that the inflow is only strengthening. ${ }^{42}$ The international research project "Challenges of Nations," carried out in spring 2016, investigated the greatest problems in 24 different countries all over the world and diagnosed migration and the integration of migrants as the primary problem faced by seven European societies. In Austria, Sweden, Switzerland, Belgium, The Netherlands, and Great Britain, between 33 and 66 percent of people described migration as their country's biggest challenge. Interestingly, the results reached a record high in Germany, where 83 percent of respondents

38 Buzan et al., The European Order Recast, 120.

39 Wæver et al., Migration and the New Security, 42.

${ }^{40}$ EU's external border force, Frontex, reported over 1,800,000 illegal border crossings into Europe in 2015. Annual Risk Analysis 2016 (Warsaw: Frontex, 2016), http://frontex.europa.eu/assets /Publications/Risk_Analysis/Annula_Risk_Analysis_2016.pdf.

41 "Migration and migrant population statistics," Eurostat, May 2016, http://ec.europa.eu/eurostat /statistics-explained/index.php/Migration_and_migrant_population_statistics.

42 All trends and figures are available from the International Organization for Migration at http:// migration.iom.int/europe/. 
pointed to migration and integration. The fact that this result is almost two and a half times greater than that of a similar study conducted in 2015, when only 35 percent thought immigration was the biggest problem, shows the avalanche scale of deepening societal insecurity. ${ }^{43}$

According to George Friedman, the notion of the European nation originated from a group of people living in a fairly defined area, sharing a language, a history, a set of values and, in the end, a tautological self-concept: a Frenchman knew himself to be a Frenchman and simultaneously was recognized by other Frenchmen to be French. ${ }^{44}$ This definition of nationhood could transform into a near-mysticism of romantic nationalism and at times, into vicious xenophobia, but in general it worked well in practice. The obvious challenge contemporary Europe has to face arises from the heart of the theory that the nation - and therefore, national identity - is something into which one is born, not migrated.

Friedman poses a difficult question: What does one do with the foreigner who comes to your country and wants to be a citizen? And further: what happens when a foreigner comes to your country and wants to be not only a citizen, but to become part of the society? Citizenship can be granted; nevertheless, it is difficult both to adopt and to share an identity that is not expressed in official documents but in a reciprocal sentiment of belonging, rooted in mutual recognition. National identity for Europeans is not traditionally rooted in choice. The issue of the assimilation of immigrants into Europe creates a fault line that, under sufficient stress and appropriate circumstances, could rip Europe apart, and not only because of the large number of immigrants. European states are not configured to deal with immigration. They have a definition of nationhood that is incompatible in fundamental ways with immigration. Assimilation in such a situation is not impossible, but it is enormously more difficult. These features inherent in the nation and in society must be taken into consideration in the context of the current migration crisis. The reasons for this are the sheer scale and the different cultural background of migrants. Both factors are crucial to the conceptual frame of societal security.

Migration in the societal context needs to be conceptualized with respect to two factors. The first one is the fact that immigrants originate from non-European cultures, which greatly hinders their melting into the host societies. While

43 The research took place in February and March 2016. It surveyed 2,104 people over 14 years old in Germany (and 27,600 all over the world). More details, including results and methodology, are available at GfK Verein, http://www.gfk-verein.org/en/research/studies/challenges-nations.

${ }^{44}$ George Friedman, "A Question of Integration," Geopolitical Intelligence Report, November 8, 2005. 
the million Ukrainians who have come to Poland since the beginning of the war in Ukraine are nearly invisible on the streets of Polish cities, ${ }^{45}$ similar number of refugees from Syria, Iraq, and Afghanistan in Germany are impossible to overlook. Secondly, the massive size of migration flows in this globalized world, which also provides everyone with means of communication enabling him or her to keep in constant touch with his or her place of origin, further impairs the capacity to integrate and acculturate into a host society already weakened by multiculturalism, aging and negative demographic trends. Both factors contribute to mass migration becoming tantamount to Grand Replacement ${ }^{46}$ - a great replacement in which although the number of people in the country remains roughly the same, they are no longer German, French, or Belgian in the cultural, and therefore societal, sense.

Societal undercurrents in reaction to migration have been palpable for several years - not in mainstream academia or political discourse, but rather on the outskirts of official debate. Nevertheless, these currents of thought run deeply and feed off the same issues that now shape the political landscape in Europe. Already in 1982, a group of fifteen professors published the so-called Heidelberg Manifesto, which emphasized that nations have a natural right to preserve their identity when it is threatened because integration of large masses of foreigners is not possible for systemic reasons. ${ }^{47}$ Three years later a brochure, Germany without Germans, called for an alternative immigration policy. One of its authors, Robert Hepp, who coined the term "self-genocide," published a provocative book in 1988, The Final Solution to the German Question: Foundations of Political Demography in the Federal Republic of Germany, arguing that the costs of mass immigration from culturally different areas outweigh its benefits and warning of its disastrous consequences. ${ }^{48}$ At the beginning of the 1990s, Assault on Europe: Asylum Seekers and Economic Migrants: Are we in Danger of a New Migration Period? by Manfred Ritter called open

45 In 2015, Polish consular and diplomatic offices in Ukraine issued 922,240 visas to Ukrainian citizens. Between January 1 and February 29, 2016, a further 154,515 visas were issued. In comparison, in the same period of 2016 only 110,044 visas were issued. These numbers do not account for irregular migrants in Poland. Data based on the special report prepared by the Polish Office for Foreigners, Raport na temat obywateli Ukrainy, available at http://udsc.gov.pl/statystyki /raporty-specjalne/biezaca-sytuacja-dotyczaca-ukrainy/.

46 A phrase coined by the French writer Renaud Camus.

47 The whole text of the manifesto can be found in Appendix E of Michael S. Teitelbaum, The Fear of Population Decline (Orlando, FL: Academic Press, 2013).

48 Robert Hepp, Die Endlösung der Deutschen Frage: Grundlinien einer politischen Demographie der Bundesrepublik Deutschland (Tübingen: Hohenrain, 1988). 
border policies "a march into the abyss" that would lead straight to "the hell of multicultural society." 49 While Ritter was under investigation for propagating hate speech, his book hit the bestseller charts. Jan Werner diagnosed the unsuccessful integration of migrants in Invasion of the Poor: Asylum Seekers and Illegal Migrants ${ }^{50}$ and in 2010 Thilo Sarrazin wrote another bestseller, Germany Is Abolishing Itself, which reiterated all the points raised by Hepp nearly two decades earlier. ${ }^{51}$ Hepp, when asked about Sarrazin's book, said that the word "Germany" in the title is a euphemism, a smoke screen, and a substitute for something that cannot be called by its true name. The problem is not, after all, the abolition of the state, but the "self-destruction of the German nation." The state will survive, he said, whereas it is society that is faced with the threat of extinction. ${ }^{52}$

The problems associated with a dying Europe, albeit a Europe understood as a social, not a political reality, were also raised in other countries. Walter Laqueur wrote about it in his book The Last Days of Europe: An Epitaph for an Old Continent ${ }^{3}$ and Bruce Thornton in Decline and Fall. Europe's Slow Motion Suicide. ${ }^{54}$ The themes of demographics and immigration also appeared in the pamphlet-like Death of the West written by Pat Buchanan ${ }^{55}$ as well as Londonistan penned by Melanie Phillips. ${ }^{56}$ In Switzerland, Beat Christoph Bäschlin published Islam Will Devour us! Islamic Assault on Europe and the European Associates of this Invasion, in which the fatal consequences of mass immigration are analyzed in the context of Islam. ${ }^{57}$ This topic has been taken up by another Swiss author, Dudo Erny, who in Disappearing Europeans emphasized the discrepancy

49 Manfred Ritter, Sturm auf Europa - Asylanten und Armutsflüchtlinge: Droht eine neue Völkerwanderung? (Mainz: Hase \& Koehler, 1990).

${ }^{50}$ Jan Werner, Die Invasion der Armen. Asylanten und illegale Einwanderer (Mainz: Hase \& Köhler, 1992).

51 Thilo Sarrazin, Deutschland schafft sich ab: Wie wir unser Land aufs Spiel setzen (München: DVA, 2010).

52 Tomasz Gabiś, “Masowa imigracja w oczach Niemców (Głosy zza Odry),” Nowa Debata, January 5, 2016, http://nowadebata.pl/2016/01/05/masowa-imigracja-w-oczach-niemcow-glosy-zza -odry/.

53 Walter Laqueur, The Last Days of Europe: Epitaph for an Old Continent (New York: St. Martin's Press, 2007).

${ }^{54}$ Bruce S. Thornton, Decline and Fall: Europe's Slow Motion Suicide (New York: Encounter Books, 2013).

55 Patrick J. Buchanan, The Death of the West: How Dying Populations and Immigrant Invasions Imperil Our Country and Civilization (New York: St. Martin's Press, 2010).

56 Melanie Phillips, Londonistan (New York: Encounter Books, 2007).

57 Beat C. Bäschlin, Der Islam wird uns fressen!: der islamische Ansturm auf Europa und die europäischen Komplizen dieser Invasion (Tegna: Selvapiana-Verlag, 1992). 
between the society and the state. ${ }^{58}$ In France, long before Michel Houellebecq, ${ }^{59}$ a peaceful takeover by foreign culture was depicted by Jean Raspail in the Camp of the Saints. 60

The decisive dimension of the presence of migrants is that it changes the balance of the indigenous European population. Although there is certainly no proportional formula, simple numbers can change identities. It is primarily a matter of how relative numbers interact with the absorptive and adaptive capacities of society, and whether migrants seek to maintain their identity rather than adapting. ${ }^{61} \mathrm{~A}$ more assertive trend among migrants seems to a certain extent to result from failures of integration, and partially as well from imported fanaticism. Most scholars point to the hidden hand of socio-economic issues, which are unquestionably prominent but still play a subservient role to the main set of identitive factors triggering the societal security dilemma in Europe. As Wæver voiced it, "Threats strengthen identities at which they are aimed. Attempts to suppress an identity may work, but equally they may reinforce the intensity with which the group coheres." ${ }^{2}$ This mechanism was set in motion when waves of migration hit the European borders and further accelerated with the securitization of migration that has led to the emergence of Festung Europa.

\section{Politicization and Securitization of Migration in Europe}

The issue of migration has impacted European politics for several decades. It did not appear in 2015 out of the blue. Nonetheless, the ongoing migration crisis can be characterized with "before and after" due to profound differences in approaching the problem at those times. Before the crisis, migration was politicized, i.e. the state was expected to cope with it within the standard political system as "part of public policy, requiring government decision and resource allocations, or more rarely some form of communal governance." 63 Irregular migration (as opposed to migration sensu stricto) was targeted by national and EU policies, ${ }^{64}$ and while the general phenomenon of immigration was somewhat

\footnotetext{
58 Erny Dudo, Das Verschwinden der Europäer (Norderstedt: Books on Demand, 2015).

${ }^{59}$ Michel Houellebecq, Soumission (Paris: Editions Flammarion, 2015).

${ }^{60}$ Jean Raspail, Le Camp des Saints (Paris: Robert Laffont, 1973).

${ }^{61}$ Wæver et al., Migration and the New Security, 45.

62 Ibid., 43.

${ }^{63}$ Buzan et al., The European Order Recast, 23.

${ }^{64}$ On the European level, three main programmes affect migration and asylum policies: the Tampere Programme (2000-2005), the Hague Programme (2005-2010), and the Stockholm Programme (2010-2014). See Elizabeth Collett, "Future EU policy development on immigration and asylum:
} 
contentious, the opinion divide was vertical, contributing to polarization of the political scene. Such polarization cut down from the highest-ranking politicians to the lowest echelons of society in both camps. This meant that one side of the debate, including but not limited to left-wing parties, non-governmental activists and groups such as Amnesty International and OpenDemocracy, fought against a so-called Fortress Europe (often embodied by Frontex) through lobbying and "No human being is illegal" campaigns. ${ }^{65}$ They contended that the European approach to immigration was at odds with human rights and could not be sustained. ${ }^{66}$

Conversely, the other side rallied under the nationalist banners of fringe political parties such as the British National Party in Great Britain, the Front National in France (under the leadership of Jean-Marie Le Pen, before his daughter took the leading position), the Freedom Party in Austria, Lijst Pim Fortuyn in The Netherlands (although Fortuyn, its founder and leader, explicitly distanced himself from "far-right" politicians) and Vlaams Belang in Belgium. Those parties exhibited "immiskepticism" and advocated things that were not included in the official narratives of the political mainstream. Still, the issue of immigration was only one of many items on their political agendas and not even the most important one. Furthermore, because their argumentation was compelling only to the electoral margins, the political consensus could deny these "radical" parties and movements any right of representation. Arguably, this cordon sanitaire would guarantee that those political parties who did not fit into the political status quo were securely marginalized. If any such party increased its sphere of influence, as did Jörg Haider's Freedom Party in Austria in 2000, isolation and freezing of diplomatic cooperation would be immediately applied by fellow member states.

The escalation of the migration problem in 2015 prompted European Union leaders to reconsider their policies (although, on the European level, there is currently no real single immigration policy ${ }^{67}$ ), not only due to the sheer number

Understanding the challenge," Migration Policy Institute Europe, Policy Brief Series, Issue No. 4. May 2014.

65 The campaigns were inspired by a speech by Elie Wiesel, Holocaust survivor and Nobel Peace Prize winner, who said: "You who are so-called illegal aliens must know that no human being is illegal."

${ }^{66}$ For more on this issue, see Andrew Geddes, Immigration and European integration: Beyond fortress Europe? (Manchester: Manchester University Press, 2008); and Robert Dover, "Towards a Common EU Immigration Policy: a Securitization Too Far," European Integration 30, No. 1 (2008): 113-30.

${ }^{67}$ A vision for this policy was presented in the Commission communication "Towards a Common Immigration Policy" on December 5, 2007. The principles serving as the foundation for formulation of such policy can be found in the Communication from the Commission to the European Parliament, 
of migrants but also because of the fact that only four or five member states were receiving around 70 percent of the refugees crossing the external borders into the EU. In 2015 German chancellor Angela Merkel, a staunch proponent of open border policies and Willkommenskultur, proposed a new system of quotas to distribute non-EU asylum seekers across the EU member states. Under the Commission's emergency system for resettling asylum seekers, the 28 member states would be required to accept asylum seekers in proportion to the size of their economies, unemployment rates, and populations. The resulting quota is based on an algorithm that gives population size a weight of 40 percent, economic growth 40 percent, unemployment ten percent, and ten percent for previous engagement with asylum seekers. ${ }^{68}$ Indeed, on September 22, 2015, European Union interior ministers meeting in the Justice and Home Affairs Council approved a plan to relocate 120,000 asylum seekers over two years. ${ }^{69}$ However, support for the scheme was tenuous at best, and several of the countries that initially supported it withdrew as the crisis continued. For instance, in Poland the document was signed just before a change of government. Then-Prime Minister Ewa Kopacz assured the EU that Poland was both willing and ready to accept as many refugees as possible. ${ }^{70}$ Her declarations were uttered without any societal support. Consequently, the next elections were won by the Law and Justice Party, which established itself in opposition to the pro-immigration stance of the Civic Platform, then in power. Thus, it should not come as a surprise that, seizing his first chance to opt out in the wake of the November 2015 Paris terrorist attacks, Konrad Szymański, Poland's European Affairs Minister-designate, stated that he saw no possibility of acquiescing to the EU refugee relocation scheme in Poland, due to security concerns.

the Council, the European Economic and Social Committee and the Committee of the Regions of 17 June 2008 - A Common Immigration Policy for Europe: Principles, actions and tools, available at EUR-Lex, http://eur-lex.europa.eu/legal-content/EN/TXT/?uri=URISERV\%3Aj10001. The future of EU migration policy is presented at the EU Immigration Portal: http://ec.europa.eu /immigration/who-does-what/more-information/the-future-of-the-eu-migration-policy-general -context-and-new-initiatives_en.

${ }^{68}$ European Commission. European Solidarity: A Refugee Relocation System, http://ec.europa.eu /dgs/home-affairs/what-we-do/policies/european-agenda-migration/background-information /docs/2_eu_solidarity_a_refugee_relocation_system_en.pdf.

${ }^{69}$ European Commission. Press Releases. European Commission Statement following the decision at the Extraordinary Justice and Home Affairs Council to relocate 120,000 refugees, September 22, 2015, http://europa.eu/rapid/press-release_STATEMENT-15-5697_en.htm.

70 "Kopacz: przyjmiemy uchodźców, bo to nasz obowiązek, test na przyzwoitość," TVN24, September 10, 2015, http://www.tvn24.pl/wiadomosci-z-kraju,3/kopacz-przyjecie-uchodzcow-jest -naszym-obowiazkiem,576031.html. 
In fact, passive resistance to the scheme has been so significant that as of April 2016, EU members have collectively fulfilled only 15 percent of the European Resettlement Scheme and less than 1 percent of the European Relocation Plan. ${ }^{71}$ For that reason, on May 4, 2016, the European Commission presented a draft regulation intended to overhaul the existing Dublin Regulation that dictated the asylum application system in Europe. That proposal was reinforced by an initiative to charge member states that do not implement the new system a "solidarity contribution" of 250,000 euro per asylum applicant. ${ }^{72}$ This decision further alienated member states' societies and did not help with policy implementation. In fact, according to the European Asylum Support Office, of 32 states that volunteered to accept refugees, eleven did not admit a single person. Among those countries one can find Denmark, Austria, Great Britain, Hungary, Norway, Italy, Greece, Iceland, Slovakia, and Liechtenstein. ${ }^{73}$ While the Visegrad countries (Hungary, Czech Republic, Slovakia, and Poland) were the most vocal in resistance, and therefore incurred the odium of Brussels for their apparent lack of solidarity, Czech president Miloš Zeman, Hungarian Prime Minister Viktor Orbán, and Slovakian leader Robert Fico were not the only European leaders to reject and ridicule the European approach to migration; they just did so openly. In other countries, the words were more temperate, but the action (or lack thereof) speaks volumes. The "Refugees welcome" pro-migration manifestations became less numerous and significant in terms of societal impact and attendance. There is no alternative to PEGIDA that gathers similar crowds in any of the EU countries.

\section{Migration Crisis as the Catalyst of Societal Insecurity}

When looking for the factors causing such behavior, it is usually pointed out that in the last couple of years Europe has seen a real surge of anti-establishment

${ }^{71}$ Solon Ardittis, "A Global Resettlement Scheme for Refugees in the EU," News Deeply, May 10, 2016, https://www.newsdeeply.com/refugees/op-eds/2016/05/10/a-global-resettlement -scheme-for-refugees-in-the-e-u.

72 Matthew Holehouse, "EU to fine countries 'hundreds of millions of pounds' for refusing to take refugees," The Telegraph, May 3, 2016, http://www.telegraph.co.uk/news/2016/05/03/eu-to-fine -countries-that-refuse-refugee-quota/.

73 According to the European Asylum Support Office in June 2016, EU countries recorded 120,471 applications for international protection, the highest number of applications since November 2015 and a higher level than June 2015, when 97,462 applications were recorded. Detailed statistics regarding trends can be found at https://www.easo.europa.eu/information-analysis/analysis -and-statistics. 
parties. These parties are commonly referred to as the "far-right," "hard-right," or "populist" parties, but this essentialist approach muddles the picture, because some of them (especially in economic terms, but not only) are firmly rooted in the leftist tradition. These parties have one thing in common: they are parties of protest that do not want to work within the current political status quo. On the contrary, their main political objectives are aimed at overturning the establishment. They want to change their governments' present strategic objectives not by a revolution, but by using perfectly acceptable political means. Another peculiar feature of the anti-establishment parties is the fact that migration for them is now a top priority issue and question of security. They have different political programs and priorities. However, if there is something that binds them together, it is a negative stance on migration in its political (security), economic (re-distribution of resources) and cultural (Islamization) dimensions. In France, the Front National is the main political force opposing the "quiet conquest" 74 by Muslim migrants. At present it has 27 percent of steadily growing support among the electorate, ${ }^{75}$ while its leader, Marine Le Pen, is one of the leading candidates in France's upcoming presidential elections. The United Kingdom Independence Party, with a 17 percent share of the vote, ${ }^{76}$ had its leader Nigel Farage (MEP) ferociously campaigning for Brexit as the only means of securing the UK's borders against the inflow of migrants, especially from other EU countries. In Denmark, the Danish People's Party (Dansk Folkeparti), with 20 percent support, has become the second political power in the country ${ }^{77}$ and also proposes strict anti-migration policies. For instance, the party's deputy leader called for a ban on Muslim asylum seekers. ${ }^{78}$ The fact that one-third of Danes believe they are at war with Islam only helps their cause. ${ }^{79}$ In The Netherlands, the Party for

74 The phrase comes from the magazine article by Rachel Binhas, "Les Frères musulmans français: la conquête tranquille,” Valeurs Actuelles, July 28, 2016, http://www.valeursactuelles.com/les-freres -musulmans-francais-la-conquete-tranquille-63871.

75 Current political standing of Front National is announced on its website at http:/ /www.frontnational .com/terme/sondages/.

76 "Poll results: Support for conservatives and UKIP up," ITV, May 4, 2016, http://www.itv.com /news/wales/2016-05-04/poll-results-support-for-conservatives-and-ukip-up/.

77 "Record Gains for Anti-Immigrant Party in Danish Vote," Breitbart, June 20, 2015, http://www .breitbart.com/national-security/2015/06/20/record-gains-for-anti-immigrant-party-in-danish -vote/.

78 "Leading Danish politician calls for ban on Muslim asylum seekers," Deutsche Welle, July 27, 2016, http://www.dw.com/en/leading-danish-politician-calls-for-ban-on-muslim-asylum-seekers /a-19432668.

79 “1/3 Duńczyków uważa, że ich kraj jest na wojnie z islamem,” Euroislam.pl, August 2, 2016, http://euroislam.pl/13-dunczykow-uwaza-ze-ich-kraj-jest-na-wojnie-z-islamem/. 
Freedom (Partij voor de Vrijheid) is the current number one, as Geert Wilders has announced proudly on his weblog. ${ }^{80}$ Its "sister party" in Austria, the Freiheitliche Partei Österreichs, is currently at 30 percent and aspires to be the leading political power in Austria, with a possible future President in waiting (Norbert Hofer). ${ }^{81}$ The Austrian Chancellor, Christian Kern, announced recently that the migration crisis might lead to a state of emergency, ${ }^{82}$ but Hofer clearly spiraled the bidding for votes upward with calls for secure borders, a burqa ban, blocking entry of persons bearing Turkish passports, and withdrawal from the EU. The Swedish Democrats (Sverigedemokraterna) are often called a single-issue party ${ }^{83}$ because migration is the central point on their political agenda. Clearly, Swedish society concurs, as the party currently holds first place in the country's politics in spite of a cordon sanitaire imposed by other parties present in the Riksdag. ${ }^{84}$ In Finland, the Finns Party (Perussuomalaiset, formerly the True Finns) has been a member of the ruling coalition since $2015,{ }^{85}$ while in Norway, the Progress Party (Framstegspartiet) has recorded its best result since 2011 in a recent survey. ${ }^{86}$ Finally, in Italy, the Northern League (Lega Nord) secured nearly 20 percent of the vote in the last elections and its leader, Matteo Salvini, has a 33 percent approval rating, securing him a position as a rising political star. ${ }^{87}$

Most scholarship still treats these radical parties as if they were marginal or fringe elements and assumes their support to be rather unstable. ${ }^{88}$ As for the reasons for the increased popularity of radical parties, political science lacks a unanimous and convincing theory. Regarding electoral preferences, several

${ }^{80}$ Geert Wilders Weblog, http://www.geertwilders.nl/index.php/94-english/1997-pvv-nr-1-in -dutch-polls.

${ }^{81}$ Philip Olterman, "Austrian far-right party's triumph in presidential poll could spell turmoil," The Guardian, April 25, 2016, https://www.theguardian.com/world/2016/apr/25/austrian -far-right-partys-triumph-presidential-poll-turmoil-norbert-hofer.

82 "Austria rozważa wprowadzenie stanu wyjątkowego przez uchodźców," NDIE.pl, August 18, 2016, http://ndie.pl/austria-rozwaza-wprowadzenie-stanu-wyjatkowego-uchodzcow/.

83 Gissur Ó. Erlingsson, Kåre Vernby, and Richard Öhrvall, "The single-issue party thesis and the Sweden Democrats," Acta Politica 49, No. 2 (2014): 196-216.

84 Oliver Lane, "Anti-Migration Sweden Democrats Once Again Largest Party In attest Opinion Poll," Breitbart, January 21, 2016, http://www.breitbart.com/london/2016/01/21/anti-migration -sweden-democrats-once-again-largest-party-in-latest-opinion-poll/.

85 Richard Milne, "True Finn finds power harder than protest," The Financial Times, October 14, 2015, http://www.ft.com/cms/s/0/6fe11572-6d96-11e5-8608-a0853fb4elfe.html.

86 Tor Ingar Oesterud, "Progress Party still on the upswing on new poll," Norway Today, February 29, 2016, http://norwaytoday.info/news/progress-party-continuing-recovery-on-remeasuring/.

87 Julia Paravicini, “Italy's far right jolts back from dead," Politico, March 2, 2016, http:/ /www.politico .eu/article/italys-other-matteo-salvini-northern-league-politicians-media-effettosalvini/.

88 Terri E. Givens, Voting Radical Right in Western Europe (Cambridge: Cambridge University Press, 2005). 
early studies of the far-right parties adopted the most popular explanation, that post-industrialization and globalization have restructured the social strata in Western societies, thus creating new "pools of frustration" to be exploited by politicians. ${ }^{89}$ This explanation attributes growing political support for radical parties to fear ${ }^{90}$ or economic crisis..$^{91}$ Others argue that the voters' choices should be explained not in economic terms but rather in terms of socio-cultural policy preferences, ${ }^{92}$ which have become more salient in Europe. Theodore Kemper bases his analysis on a grievance theory, ${ }^{93}$ while Jeff Goodwin and James Jasper discuss in-group versus out-group dynamics. ${ }^{94}$ Finally, migration, ${ }^{95}$ ethnic competition, ${ }^{96}$ and discontent ${ }^{97}$ are proposed as the ultimate factors leveraging political trends. More importantly, recent studies proposing causal models to explain the success of radical parties ${ }^{98}$ seem one-dimensional when confronted with other political actors. Other studies aimed at measuring the impact of radical parties mistake correlation for causality, ${ }^{99}$ putting forward quite a tautological argument, i.e., that the increase in anti-immigrant sentiment proves that right-wing parties have played a part in fueling these negative feelings. In her

89 Jens Rydgren, ed., Class Politics and the Radical Right (New York: Routledge, 2013), 1.

90 Herbert Kitschelt, The Radical Right in Western Europe: A Comparative Analysis (Michigan: Michigan University Press, 1995).

91 Jörg Flecker, Gudrun Hentges and Gabrielle Balazs, "Potentials of Political Subjectivity and the Various Approaches to the Extreme Right: Findings in the Qualitative Research," in Changing Working Life and the Appeal of the Extreme Right, ed. Jörg Flecker (Aldershot: Ashgate, 2016), $35-61$.

92 Piero Ignazi, Extreme Right Parties in Western Europe (Oxford: Oxford University Press, 2003).

93 Theodore D. Kemper, "A Structural Approach to Social Movement Emotions," in Passionate Politics: Emotions and Social Movements, eds. Jeff Goodwin, James M. Jasper, and Francesca Polletta (Chicago: University of Chicago Press, 2009), 58-73.

94 Jeff Goodwin and James M. Jasper, The Social Movements Reader: Cases and Concepts (Chichester: Wiley-Blackwell, 2009).

95 Elisabeth Ivarsflaten, "What Unites Right-Wing Populists in Western Europe? Re-examining Grievance Mobilization Models in Seven Successful Cases," Comparative Political Studies 41, No. 1 (2008): 3-23.

96 Marcel Lubbers, Mérove Gijsberts and Peer Scheepers, "Extreme Right-Wing Voting in Western Europe," European Journal of Political Research 41, No. 3 (2002): 345-78.

97 Eric Belanger and Kees Aarts, "Explaining the rise of the LPF. Issues, discontent, and the 2002 Dutch Election," Acta Politica, 41 (2006): 4-20.

${ }^{98}$ Kai Arzheimer, "Contextual Factors and the Extreme Right Vote in Western Europe, 1980-2002," American Journal of Political Science 53, No. 2 (April 2009): 259-75; Pippa Norris, Radical Right: Voters and Parties in the Electoral Market (Cambridge: Cambridge University Press, 2005); Wouter Van Der Brug and Fennema Meindert, "Protest or Mainstream? How the European Anti-Immigrant Parties Developed into Two Separate Groups by 1999," European Journal of Political Research 42, No. 1 (2003): 55-76.

99 Michelle Williams, The Impact of Radical Right-Wing Parties in West European Democracies (New York: Palgrave Macmillan, 2006), 66. 
study, Michelle Williams entirely ignores the possibility of a bottom-up impetus or a dynamic of supply meeting demand.

While many of these propositions are partially true, they mistake effect for cause. In other words, the causal factors listed above are merely symptoms of societal insecurity, from which political radicalization is the last but not the least important emanation. By neglecting the societal factor, one may too-hastily ascribe the reaction in "mass politics" against migration 100 to a single phenomenon (racism, populism, or xenophobia) that is not able to provide a satisfactory explanation under the complex canopy of society. Only by employing the societal security framework may one delve deep into the real sources of the problem and account for the primary causal factors, instead of stopping half-way and focusing on what are merely by-products of societal insecurities. Large-scale migration from culturally alien areas leads to societal insecurity and securitizes all migration-related policies. Securitization often depends on the power and influence of the securitizing actor, which is most frequently the state or the elites, and hinges upon convincing those actors' audience, usually the society, that a given development is indeed a threat. Hence "speech acts" are important and securitization retains a very strong discursive dimension. In this case, we observe a bottom-up securitization whereby the society pushes for extraordinary measures and politicians are compelled to oblige.

Societal insecurity also exposes the discrepancy between the state and the society, which is understandable when one considers that the elites and the general public each pursue a different logic. The elites are more closely linked to the state and the public to the society. ${ }^{101}$ In those countries where the political establishment and the elite in power ignore societal insecurities, radicalization of politics ensues because Europeans are no longer satisfied with the way their interests are represented. What is more, Europeans increasingly feel that they are not represented in government in the slightest. The gap between the political elite and ordinary Europeans is so vast that democracy in the form of marking an $\mathrm{X}$ on the ballot every few years begins to fail. When the people begin to believe that their representatives do not represent them but instead are standing up for different, "foreign" constituencies, or are simply making decisions guided by incomprehensible priorities that are impossible to explain using even the most elaborate rhetoric, when they suspect that politicians do not listen to what they

${ }^{100}$ Barry Buzan and Ole Wæver, Regions and Powers: The Structure of International Security (Cambridge: Cambridge University Press, 2003), 357.

101 Wæver et al., Migration and the New Security, 82. 
have to say and do not care about their fears and needs, then there is no other choice, they need to look for new political representation.

For these reasons, the defining quality of the European radical parties is their negative stance on migration in the political (security), economic (re-distribution of resources) and cultural (Islamization) dimensions. A societal security framework allows one to understand the sources of the rising popularity of various social movements like PEGIDA, the urge to take democracy to the streets (in demonstrations, manifestations, and happenings), and the attractiveness of vigilante groups (like the Soldiers of Odin, who originated in Finland but already have branches in many different European countries) present both in the Eastern and Western part of the European Union.

When one's identity is threatened, one has to strengthen its expression. In that way, securitization implies a change of identity, a change in who "we" are, and the equating of culture with politics. Culture, thus, becomes a security policy. ${ }^{102}$ Over time, the physical and symbolic boundaries dividing communities may be reinforced even further. ${ }^{103}$ Suffice it to mention the ubiquitous calls for a ban on burqas and burkinis to see how culture merges with security policy. ${ }^{104}$ The growing chasm between the political elites and ordinary citizens both enables and forces societies to maintain their own security. Buzan explains that societies can either react to threats with activities carried out by the community itself or by forcing the threat onto the state's agenda. ${ }^{105}$ The latter trend is visible in the movement of mainstream parties toward anti-immigration or xenophobic discourse in mass politics, ${ }^{106}$ the former is supported by the fact that various mostly non-state - actors have mobilized a resistance against integration of their states into the EU, based on the security claim that integration threatens their national identity. ${ }^{107} \mathrm{~A}$ similar response can be observed to the Muslim presence in Europe.

In 1993, Wæver observed that although most European states have always had minorities, some of which have been or even now are irredentist, they have considered themselves relatively homogeneous, with a strong sense of national

102 Ibid., 70.

103 Watson and Boag, "Ethnicity and Religion."

104 In Cannes, France, municipal authorities justified their ban saying that the burkini "refers to an allegiance to terrorist movements which are at war with us." See "Burkinis banned on France's Cannes beaches by mayor," The Telegraph, August 11, 2016, http://www.telegraph.co.uk /news/2016/08/11/burkinis-banned-on-cannes-riviera-beaches-by-french-mayor/.

105 Buzan et al., The European Order Recast, 122.

106 Wæver et al., Migration and the New Security, 158.

107 Buzan and Wæver, Regions and Powers, 356. 
community founded on shared history, ethnic identity, language, culture and political experience. ${ }^{108}$ This relative cultural and ethnic homogeneity has been transformed into cultural and ethnic heterogeneity and these factors have lost their capacity to bind the societies and at the same time the nation state has declined in importance. States weakened by the institutions and mechanisms of the European Union from without and by their own changing societies from within are more vulnerable when faced with mass migration. Societal factors move into the vanguard of radicalized politics and securitized migration becomes a source of low-intensity "societal wars." This does not mean regular, structural violence, but random clashes along cultural lines in various configurations. ${ }^{109}$

These clashes can involve a minority against the state, as when police cars are fired upon with air-guns or stoned, and when those perceived as representatives of the state are attacked. ${ }^{110}$ But with increasing regularity, they take place along minority vs. majority lines or, more recently, the migrants vs. the autochthonous. On July 14, 2016, there was an attack in Nice, as the result of which 84 people were killed and more than 300 were injured. ${ }^{111}$ Four days later, on July 18, a 17-year-old refugee from Afghanistan attacked passengers on a train in Würzburg with a machete. ${ }^{112}$ In the following week, on July 22, an 18-year-old of Iranian origin opened fire in the Olympia shopping center in Munich, killing 9 people and then committing suicide. ${ }^{113}$ On July 24 , a refugee from Syria wounded 15 people by detonating an explosive device in Ansbach, ${ }^{114}$ while the next day another Syrian killed his Polish co-worker with a machete and heavily wounded

108 Wæver et al., Migration and the New Security, 158.

109 For an excellent analysis of the political responses to cultural conflict see Per Mouritsen, "Political responses to cultural conflict: Reflections on the ambiguities of the civic turn," in Constituting Communities: Political Solutions to Cultural Conflict, ed. Per Mouritsen and Knud Erik Jørgensen (Basingstoke: Palgrave Macmillan, 2008), 1-30.

110 In an interview for Radio Télévision Suisse, Fabrice Balanche from the University of Lyon speaks of this problem at length. See Fabrice Balanche, Interview with Radio Télévision Suisse, Agoravox, September 30, 2014, http://www.agoravox.tv/tribune-libre/article/des-mini-etats-islamiques -en-46961.

111 Alan Yuhas, Matthew Weaver and Bonnie Malkin, "Bastille Day truck attack: what happened in Nice," The Guardian, July 16, 2016, https://www.theguardian.com/world/live/2016/jul/14/nice -bastille-day-france-attack-promenade-des-anglais-vehicle.

112 "Germany axe attack: Assault on train in Wuerzburg injures HK family," BBC News, July 19, 2016, http://www.bbc.com/news/world-europe-36827725.

113 Catherine E. Shoichet, Ralph Ellis and Jason Hanna, "Munich shooting: 9 victims, gunman dead, police say,” CNN, July 23, 2016, http://edition.cnn.com/2016/07/22/europe/germany-munich -shooting/.

114 Frederic Pleitgen, Tim Hume and Euan McKirdy, "Ansbach bomber pledged allegiance to ISIS," CNN, July 26, 2016, http://edition.cnn.com/2016/07/24/world/ansbach-germany-blast/. 
two people in Reutlingen near Stuttgart. ${ }^{115}$ Finally, on July 26 two teenage supporters of ISIS committed the ritual killing of a Catholic priest in a church of Saint-Etienne-du-Rouvray (Normandy, France). ${ }^{116}$ While these incidents, with the exception of the Nice terrorist attack, were relatively low-intensity violence, their frequency and the palpable "us versus them" pattern might spiral out of control on the purely societal level. In fact, Patrick Calvar, France's director of domestic intelligence, estimated that "the confrontation [between communities] is inevitable," hinting that another large scale terrorist attack in France might unleash a civil war. ${ }^{117}$

\section{Conclusions}

The application of the societal security concept, with its insistence on the importance of migration as a security issue, has brought about a structural change in analysis of the totality of societal experience by inverting traditional security studies, taking them from a purely "top down," neo-realist analysis of political processes to a "bottom up" investigation, addressing the societal "grass roots" instead of focusing on the elites. On the macro-level, in the context of the current migration crisis, the theory allows for examination of the societal element in the security complex and its influence on the processes triggered by elite-driven political projects. On the micro-level, this approach enables exploration of how societal agency and the vagaries of cultural constructs work within the nexus of societal fragmentation and the societal security dilemma. By including strong cultural aspects it is possible to substantiate the validity of the concept through empirical study, and simultaneously provide a more thorough understanding of entangled, intertwined phenomena on the regional level.

Undoubtedly, as this paper shows, the European migration crisis has been a catalyst for a societal security dilemma that is inducing and accelerating change on the societal level. The table below summarizes the political and societal results of migration, both before and after the crisis.

115 Caroline Mortimer, "German machete attack: Syrian refugee kills woman and injures two other in Reutlingen,” The Independent, 24 July, 2016, http://www.independent.co.uk/news/world/europe /german-machete-attack-stuttgart-reutlingen-crime-knife-attack-a7153561.html.

116 Kim Wilsher and Julian Borger, "ISIS attackers forced French priest to kneel before he was murdered, hostage says," The Guardian, July 26, 2016, https://www.theguardian.com/world/2016 /jul/26/men-hostages-french-church-police-normandy-saint-etienne-du-rouvray.

117 John Vincour, "Averting France's War of All Against All," The Wall Street Journal, July 18, 2016, http://www.wsj.com/articles/averting-frances-war-of-all-against-all-1468870986. 
Table 1: Migration Crisis as a Catalyst

\begin{tabular}{|l|l|l|}
\cline { 2 - 3 } \multicolumn{1}{l|}{} & Before the Crisis & After the Crisis \\
\hline Focus on & Irregular migration & $\begin{array}{l}\text { All types of migration and migration- } \\
\text { related policies }\end{array}$ \\
\hline Political Result & $\begin{array}{l}\text { Politicization (one of many issues; the } \\
\text { state is expected to cope within the } \\
\text { standard political system) }\end{array}$ & $\begin{array}{l}\text { Securitization (the most important } \\
\text { issue; a threat that requires } \\
\text { extraordinary measures) }\end{array}$ \\
\hline Societal Result & Polarization (vertical, fringe parties) & $\begin{array}{l}\text { Radicalization (horizontal, political } \\
\text { elites versus their societies) }\end{array}$ \\
\hline
\end{tabular}

The societal security concept provides an alternative framework for cutting through the Gordian knot of identities and cultures and their causal roles in the context of the migration crisis and societal insecurity, the volatile result of which is political radicalization. Unfortunately, since the causal factor of identity is so dangerous in Europe, politicians have made a tacit agreement to mention it only in a positive context. Donald Horowitz argued that while elites often shape national identity, they rarely create it. ${ }^{118}$ Jürgen Habermas predicted that governments cannot continue to suppress crippling dissent within their societies and that they will have to admit that "they are at their wits' end." 119 In the end, given the still-increasing rift between the political and the societal, if the people are incessantly chastised and penalized for their concerns about migration, they will soon be forced to take action against their own state in civil disobedience.

Finally, the developments analyzed in this paper imply the increasing importance of societal security given the ongoing migration crisis. At the same time, the societal security factor is to a great extent ignored by the European political establishment, for whom Fortress Europe, Festung Europa, is a worst-case scenario. Jean-Claude Juncker even lamented that "borders are the worst invention ever." 120 Nevertheless, political actors bound neither by political nor cultural borders, remind us of John Rawls' warning that "to tear down the walls of the state is not... to create a world without walls, but rather to create a world with thousands of petty fortresses." ${ }^{121}$ Festung Europa may be created from without by

118 Donald L. Horowitz, The Deadly Ethnic Riot (Berkeley: University of California Press, 2001), 21.

119 Jürgen Habermas, "A Search For Europe's Future: And the Wheels Stopped Turning," Der Spiegel, June 18, 2008, http://www.spiegel.de/international/europe/0,1518,560549,00.html.

120 Mat Dathan, “'Borders are the worst invention ever!' EU chief Jean-Claude Juncker widens rift with European leaders as he calls for open borders," Daily Mail, August 22, 2016, http://www .dailymail.co.uk/news/article-3752939/Borders-worst-invention-EU-chief-Jean-Claude-Juncker -widens-rift-European-leaders-calls-borders-opened.html.

121 John Rawls, The Law of Peoples (Cambridge, MA: Harvard University Press, 1993), 39. 
tightening borders against mass migration or from within by reactions to societal clashes and political radicalization. The decisive issue for Europe is whether its societies will stop calling the state back in, either because the nation states have given their powers to the EU or because of the futility of such endeavors. When societal security concerns escalate to the point of securitization, migration becomes the fulcrum of the political agenda. This can be observed in those European countries, mainly in Central and Eastern Europe, where leading political forces have taken up a staunch anti-migrant position. ${ }^{122}$ In a situation where mass migration is perceived as an existential threat on the societal level, thereby triggering societal insecurity, but is ignored by the political elites, societies start looking for other political representation or act independently of the state (social movements, demonstrations, vigilante groups). In the former case, we can observe the radicalization of politics and the rise to power of new political forces, as migration is not only politicized, but framed as a security issue on the policy agenda. In the latter case, escalating societal tensions along cultural lines can have a damaging impact both on society and the state. Arguably, both trends can be a stimulus for further political fragmentation and regionalization within Europe, and both are conducive to violence.

122 “Premier Czech: Nie chcemy w kraju silnej muzułmańskiej mniejszości," Polskie Radio, August 23, 2016, http://www.polskieradio.pl/5/3/Artykul/1658635,Premier-Czech-nie-chcemy-w-kraju -silnej-muzulmanskiej-mniejszosci. 